\title{
Analysis Of connotative Meanings In Outdoor Advertisements
}

\author{
Rony Arahta Sembiring, S.S.,M.Hum \\ Faculty of Language and Arts \\ Universitas HKBP Nommensen Medan \\ ronyarahtas@gmail.com
}

\begin{abstract}
Advertisements (ads) have a power to change state of mind; it is the main core of capitalism actors to be pressed. Capitalism actors manipulate the consumer need to be commercial term. Advertisement media dan capitalism actors pull the psychological aspect. The exertion in seeing the advertisement actually refers to the commercial value by show the product on billboard along the street. Connotative meaning refers to the emotional and psychological associations a word carries with it. This research explains the insight of connotative meaning found in outdoor advertisement by relating the picture with the text (headline, subhead, slogan). The aims are to investigate the types of connotative meaning in outdoor advertisement, to ascertain the dominant type of connotative meaning and to investigate the dominant type of outdoor advertisement occur the way they are. The method in this study is qualitative method and all the collected data will be analyzed through descriptive analysis technique. The sources of the study are the texts (headlines, subhead, and slogan) in outdoor advertisement derived from the billboard. The population of this research are outdoor advertisements. The samples were taken using purposive sampling for 20 outdoor advertisements. From the analysis, the research concludes that there are three types of connotative meaning, namely positive, negative and neutral. Positive connotative meaning was found dominant in this research and there was not negative and neutral connotative meaning. Positive connotative meaning belongs to the dominant type in outdoor advertisement. Outdoor advertisement have a positive value that try to give a good point of view to attract the people attention regarding the product advertised. The findings of this study should encourage the students in studying deeper about other aspects found in outdoor advertisement.
\end{abstract}

Keywords: connotative meaning, outdoor, advertisement, positive

\section{Introduction}

Language is purely and non - instinctive method of communicating ideas, emotions and desires by means of voluntary produced symbols (Norquist, 2008). In other words, language is a system of communication used among a given community to convey their ideas, emotions, feeling, and desires by using sounds and symbols. In communication, we mostly use sounds, the sound produced by the organs of speech. "The sender" of the messages has been a speaker and "The receiver" has been a listener.

Another means of communication is the symbols. The symbols that we know mostly are letter or writing. But not many of us realize that picture is also a kind of means of communication. If we trace back to the history of our ancestors, that may be hundreds of generation back, we find that they were able to make pictures on rock faces and the walls of caves. They had to have a special significance that given to their next generation. It means that they gave message and we receive it.

Outdoor advertising, also known as out-of-home $(\mathrm{OOH})$ advertising, this is a broad term that describes any type of advertising that reaches the consumer when he or she is outside of the home. Outdoor advertising is a mass-market medium, just like broadcast. It is better used for broad messages, branding and support campaigns (Suggett, 2012).

Advertisements (ads) have a power to change state of mind; it is the main core of capitalism actors to be pressed. Capitalism actors manipulate the consumer need to be commercial 
term. Advertisement media dan capitalism actors pull the psychological aspect. They produce some products by involving advertisement agent (media) which creating the symbolic and sign values (galmour, prestige, luxurious, and new brand) upon products to change state of consumer need. Generally in advertisement, the function of advertisiments is to introduce products and services and to promote them to societies; it needs the roles of human resources such as technology and creative design. The aim of advertisements is how societies have trusts upon the products and services (Audifax, 2011).

Connotative meaning refers to the emotional and psychological associations a word carries with it. The connotative meaning of a word goes beyond its strict meaning to express the feeling, thought and images the word suggests or evokes. According to Cruse (1997), there are three types of connotative meaning, namely Positive, Negative, and Neutral of connotative meaning. Sometimes viewers are difficult to get the connotative meaning in advertisement, they don't understand the meaning what the advertisements want to convey. Based on the researcher experience, he is more difficult to get meaning in advertisement with only consist of body copy. Body copy is to explain the benefit of the product directly, and the basic concept is informative and persuasive prose that sells the product.

To minimize the different interpretation of the connotative meaning the researcher is very much interested in analyzing the relation between text and picture in order to get the connotative meaning in advertisement in outdoor advertising. Refering to the explanation above the researcher would like to give education value in adding point of view of the societies about the meaning contained/ found in one advertising. Refering to the explanation above the researcher would like to give education value in adding point of view of the societies about the meaning contained/ found in one advertising.

The problems of the study are formulated as the following

1) What types of connotative meaning are found in outdoor advertisement?

2) What is the dominant type of connotative meaning found in outdoor advertisement?

3) Why do the dominant types of outdoor advertisement occur the way they are?

\section{Method}

\section{Research Design}

In this research, qualitative descriptive method was conducted by the researcher. Bogdan and Biklen (1992:30) say that qualitative research is descriptive. The data collected are in the form of words or pictures rather than numbers. Qualitative means to find out how a theory works in a different phenomenon. So in this study, to find out of the theory of connotative meaning is used on printing media.

\section{Sources of Data}

The advertisement will be taken for a month which contained only text (headline, subhead, and slogan) and picture, and there is no body copy in the advertisement.The location of the outdoor advertisiments (billboard)s are all in Medan city.

\section{Data Collection}

The population of this research are outdoor advertisements. The samples were taken using purposive sampling for 20 advertisings. 


\begin{tabular}{|c|c|c|}
\hline Number & Text & Product \\
\hline 1. & $\begin{array}{l}\text { Caisar : Homeland Springbed : Green } \\
\text { land Spring bed }\end{array}$ & Caisar (Springbed) \\
\hline 2. & Magnum blue : Taste The Difference & $\begin{array}{l}\text { Magnum } \\
\text { (Cigarette) }\end{array}$ \\
\hline 3. & Yes : Interior and exterior & Yes (Paint) \\
\hline 4. & $\begin{array}{l}\text { Advan : Rising star Indonesia : Only A } \\
\text { star will rise }\end{array}$ & $\begin{array}{l}\text { Advan : (Mobile } \\
\text { Handphone) }\end{array}$ \\
\hline 5 & Dunhill : Gentlemen. THIS IS TASTE. & Dunhill (Cigarette) \\
\hline 6 & Galan : Find Your Fun & Galan (Cigarette) \\
\hline 7 & $\begin{array}{l}\text { Coffee : The Finest Indonesia Source. } \\
\text { The largest Indonesia Coffee Plantation. }\end{array}$ & Coffee (Beverage) \\
\hline 8 & $\begin{array}{l}\text { Samsung: The Ultimate Viewing } \\
\text { Experience. Get Into The Scene }\end{array}$ & $\begin{array}{l}\text { Sambung (Mobile } \\
\text { Handphone) }\end{array}$ \\
\hline 9 & $\begin{array}{l}\text { Dunlopillo : The First and Original } \\
\text { Health Mattress. The New Revolution for } \\
\text { mattress technology begins.... }\end{array}$ & $\begin{array}{l}\text { Dunlopillo } \\
\text { (Mattress) }\end{array}$ \\
\hline 10 & $\begin{array}{l}\text { Satria : Satria F1 Fighter. Be Different } \\
\text { with limited edition. }\end{array}$ & Satria (Motorcyle) \\
\hline 11 & Florence : The Essence of True Love. & Florence (Mattress) \\
\hline 12 & Hock : Cook With Style & Hock (Oven) \\
\hline 13 & Jazy : Jazz on Live Your Life & Jazy (Cigarette) \\
\hline 14 & $\begin{array}{l}\text { Logo : Logo is my jeans. Make your } \\
\text { move with Logo jeans. }\end{array}$ & $\begin{array}{l}\text { Logo (Jeans } \\
\text { trousers) }\end{array}$ \\
\hline 15 & $\begin{array}{l}\text { Smartfren : Be Bold.With Powerful } \\
\text { Processor and stylish design. }\end{array}$ & $\begin{array}{l}\text { Smartfren (Mobile } \\
\text { Handphone) }\end{array}$ \\
\hline 16 & Marlboro : I Will Be My Own Boss & Marlboro (Cigarette) \\
\hline 17 & Mito A77 (Fantasy, Twisst N Shoot) & $\begin{array}{l}\text { Mito A77 (Mobile } \\
\text { Handphone) }\end{array}$ \\
\hline 18 & MLD (Pleasure, Style, Confident) & MLD (Cigarette) \\
\hline 19 & Hannoch : I'm LED & Hannoch (Lamp) \\
\hline 20 & Serta (Sleep Perfectly) & Serta (Mattress) \\
\hline
\end{tabular}

\section{Discussion}

Here are some analysis Sample that represent the data:

1. The Analysis of Yes - Interior and Exterior Paint

In Yes - Interior and Exterior Paint, there are two elements of advertisement that should be identified, namely :

a. The Text : Yes : Interior and Exterior

b. Picture : Cans of paint with brightful color.

\section{First Step (Elaboration)}

a. The headline is illustrated by the picture, cans of paint with brightful color. Seeing the color, it produces the impression that using Yes- paint, surely it produces something different for the painting.

b. Variety of contrast color denotes that Yes- paint is so good for both interior and exterior.

\section{Second step (Extension)}

a. The headline means that Yes-Paint has something unique and contrast in color. At glance, people will be attractive to try to use the paint.

b. The picture shows that there are some types available in color. People just choose which color they want most.

c. Bright color of the paint surely attracts the attention of users to use the paint for making better product in painting. 


\section{Descriptors}

Descriptors are some items that could be used to determine the types of advertisement. They are presented as follows :

a. For people who want to paint something for the sake of better view, then they should choose Yes -Paint. It is good for both exterior and interior.

b. Because of contrast and brightful color, surely people are eager to try to use the paint. And all the points above are to make people eare eager to try to use the paint in accordance with the use. And this is a progress. It belongs to Positive of connotative meaning because the advertisement is intended for something good.

Yes-Paint attracts the attention of the consumers to buy the paint for best result. Also, it has luxury and eagerness to get bright paint result. Consumers will change their paint from the old one into the new one using Yes-paint.

In Yes-Paint, seen from cultural value, it has style and luxury.

\section{The Analysis of Samsung : The Ultimate Viewing Experience. Get Into The Scene}

In Samsung advertisement, there are two elements of advertisement that should be identified, namely :

a. Text: "The Ultimate Viewing Experience. Get Into The Scene".

b. Picture: Wonderful panorama.

\section{First step (Elaboration)}

a. The headline is stated by wonderful panorama. Looking at the picture, it is surely that the wonderful panorama will produce something different feeling.

b. The picture is so nice and interesting.

\section{Second step (Extension)}

a. The headline means that Samsung offer something wonderful.

b. The pictures shows the selected view with different setting

c. Further information: Samsung is one of mobile phone networks.

\section{Descriptors}

a. In the picture, the selected view is offered.

b. The colour of calm circumstance

c. Samsung emphasizes the superiority of mobile handphone.

The points above show positive of connotative meaning because it denotes something for something better.

Advertising on Sambung creates good image in using mobile handphone. Luxury image can be also found. Consumers are proud in using Samsung in every daily life.

3. The Analysis of Satria : Satria F1 Fighter. Be Different with limited edition.

In Satria advertisement, there are two elements of advertisement that should be identified, namely :

a. Text: "Satria F1 Fighter. Be Different with Limited edition ”.

b. Picture : Nice and strong motorcycle with special color.

\section{First step (Elaboration)}

a. The headline is stated by the picture of strong and nice motorcycle. At glance, from the picture, it is known that the motorcycle is good.

b. The performance is so good.

\section{Second step (Extension)}

a. The headline means that Satria F1 is one of best motorcycles in Indonesia.

b. The pictures shows the selected motorcycle

Further information : Satria is one of the best products of motorcycle.

\section{Descriptors}

a. In the picture, the performance of the motorcycle can be seen clearly

b. The color of motorcycle is very good 
The points above show positive of connotative meaning because it denotes something for something better.

Advertising on Satria F1 create good image, status and also luxury. Riding such as the motorcycle, the rider has such as happiness, and with luxury image. In addition, the strength of the motorcyle can be also found.

\section{Finding and Conclusion}

The findings were specified based on the aim at describing connotative meaning in outdoor advertisements presented as follows.

a. Positive of connotative was found as dominant type because theoretically the intension of advertisement is to attract public attention, make them feel happy, creates confident in someone, automatically the advertisers use this type.

b. Negative of connotative was found in outdoor advertisement, particularly for cigarettes. Neutral of connotative meaning was not found because it referred to the theory. This type of connotative should be omitted because the neutral connotative will never find in outdoor advertisement.

Being discussed the findings, connotative meaning gave contribution to see what was going on in the text and picture of outdoor advertisement. In this research, it was found negative connotative, but no neutral connotative meaning. It supported the theory that in fact the aim of advertising is to make other people are attracted for the products to be advertised. Outdoor advertising includes various types of promotional displays, from highway billboards to transit posters and arena placement, all geared towards communicating a message to the public. The message might be to buy a product, take a trip, vote for a politician, or give to a charity. It might even be a public service announcement.

\section{REFERENCES}

Amrin, S. 2008. Discourse Analysis: A Systematic Funtional Approach the Analysis of Text. Unpublished

Behnke, Robert J. 2002. Trout and Salmon of North America. Free Press

Bogdan, C.R \& Biklen, S.K. 1992. Qualitative Research for Education: An Introduction Theory and Methods, $2^{\text {nd }}$ edition, Needham Heights, M.A: Allyn and Bacon.

Gairns, R. \& Redman, S. 1991. Working with words. Cambridge: Cambridge University Press.

Gilson, C. \& Berkmen, W.H. 1980. Advertising: Concepts and Strategies. Toronto: New York Random House.

Jefkins, F.1994. Periklanan, $3^{\text {rd }}$ edition. Jakarta: Erlangga

Sobour, A. 2004. Analisis Teks Media. Bandung. Rodsakarya.

Taylor, Charles R. \& Chang, W. 1995, The History of Outdoor Advertising Regulation in United States, Newbury Park, CA: Sage Publications.

Van, L. T. 2005. Introducing Social Semiotics. New York: Routledge Taylor and Francis Group. 